University of Rhode Island

DigitalCommons@URI

Open Access Master's Theses

1984

\title{
THE RELATIONSHIP OF ZONING TO ENVIRONMENTAL \\ SUITABILITY: A CASE STUDY OF ESSEX CONNECTICUT
}

Richard Joly

University of Rhode Island

Follow this and additional works at: https://digitalcommons.uri.edu/theses

\section{Recommended Citation}

Joly, Richard, "THE RELATIONSHIP OF ZONING TO ENVIRONMENTAL SUITABILITY: A CASE STUDY OF ESSEX CONNECTICUT" (1984). Open Access Master's Theses. Paper 584.

https://digitalcommons.uri.edu/theses/584

This Thesis is brought to you for free and open access by DigitalCommons@URI. It has been accepted for inclusion in Open Access Master's Theses by an authorized administrator of DigitalCommons@URI. For more information, please contact digitalcommons-group@uri.edu. 
THE RELATIONSHIP OF ZONING

TO ENVIRONMENTAL SUITABILITY:

A CASE STUDY OF ESSEX CONNECTICUT

BY

RICHARD JOLY

\author{
A RESEARCH PROJECT SUBMITTED \\ IN PARTIAL FULFILLMENT OF THE \\ REQUIREMENTS FOR THE DEGREE \\ OE MASTER OF COMMUNITY PLANNING
}

UNIVERSITY OF RHODE ISLAND

1984 


\section{MASTER OF COMMUNITY PLANNING \\ RESEARCH PROJECT}

OF

RICHARD JOLY

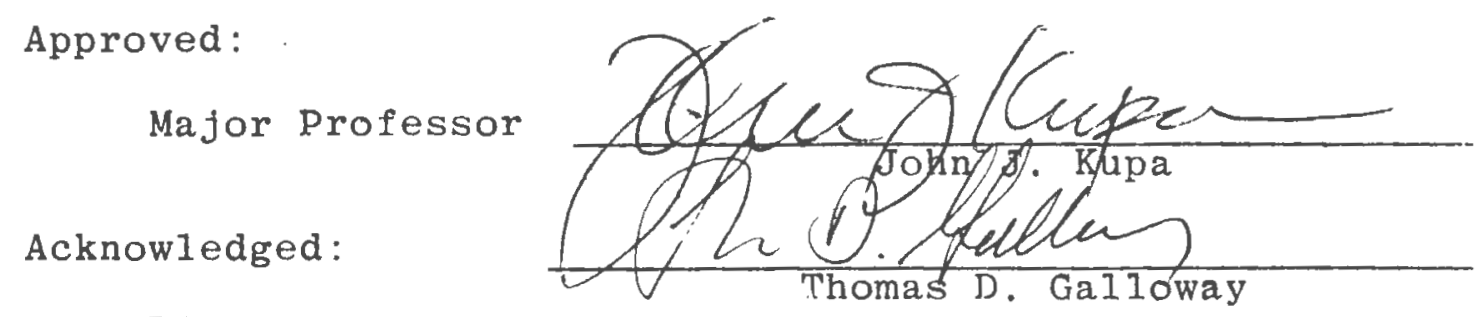

Director 


\section{Abstract}

The problem that this research project will address is the adequacy of the response of the Essex, Connecticut Zoning Regulations to the environmental suitability of the land in the town. In order to analyze this problem, the natural features of the town are first mapped. The regulations of each zoning district in town are then analyzed based on the data provided from the maps and the integration of map features. Zoning techniques are reviewed that hold the potential of improving the zoning regulation response to these natural features. The findings of this study are that many of the requirements of the Essex zoning Regulations adequately respond to the environmental constraints of the town but that some changes are needed. It is recommended that erosion and stormwater runoff controls be developed that apply to all districts in the town, and secondly that a groundwater protection district and cluster zoning provisions be incorporated in the Essex zoning Regulations. The map data also show the need for specific zoning district boundary changes. 
TABLE OF CONTENTS

$\begin{array}{llr} & & \text { Page } \\ \text { CHAPTER I } & \text { INTRODUCTION } & 1 \\ \text { CHAPTER I I } & \text { NATURAL FEATURES } & 3 \\ \text { CHAPTER II } & \text { ESSEX ZONING REGULATIONS } & 23 \\ \text { CHAPTER IV } & \text { ZONING TECHNIQUES } & 41 \\ \text { CHAPTER V } & \text { CONCLUSiON } & 53 \\ \text { BIBLIOGRAPHY } & & 55\end{array}$

i i i 


\section{CHAPTER I}

\section{Introduction}

This research project analyzes the zoning regulations of Essex Connecticut to determine how well they respond to the natural features of the town. Natural features are not the only factors used in determining zoning regulations but this project limits itself to an analysis of just natural features. These natural features include streams, ponds, wetlands, flood prone areas, aquifer recharge areas, steep slopes, erodable soils and septic system constraints. Mapping of each of these natural features is provided along with the text of this study. The value of each of these natural features and the development constraints that they cause are described. Each of the zoning districts of Essex are reviewed and specific recommendations are made concerning ways to improve the response of these districts to the environmental suitability of the land. Zoning techniques are then described that have the potential of improving the environmental responsiveness of the Essex Zoning Regulations. The zoning techniques that have been judged to be most applicable to the needs of Essex are impact zoning, overlay zoning and cluster zoning. A general analysis of each of these techniques is provided along with 


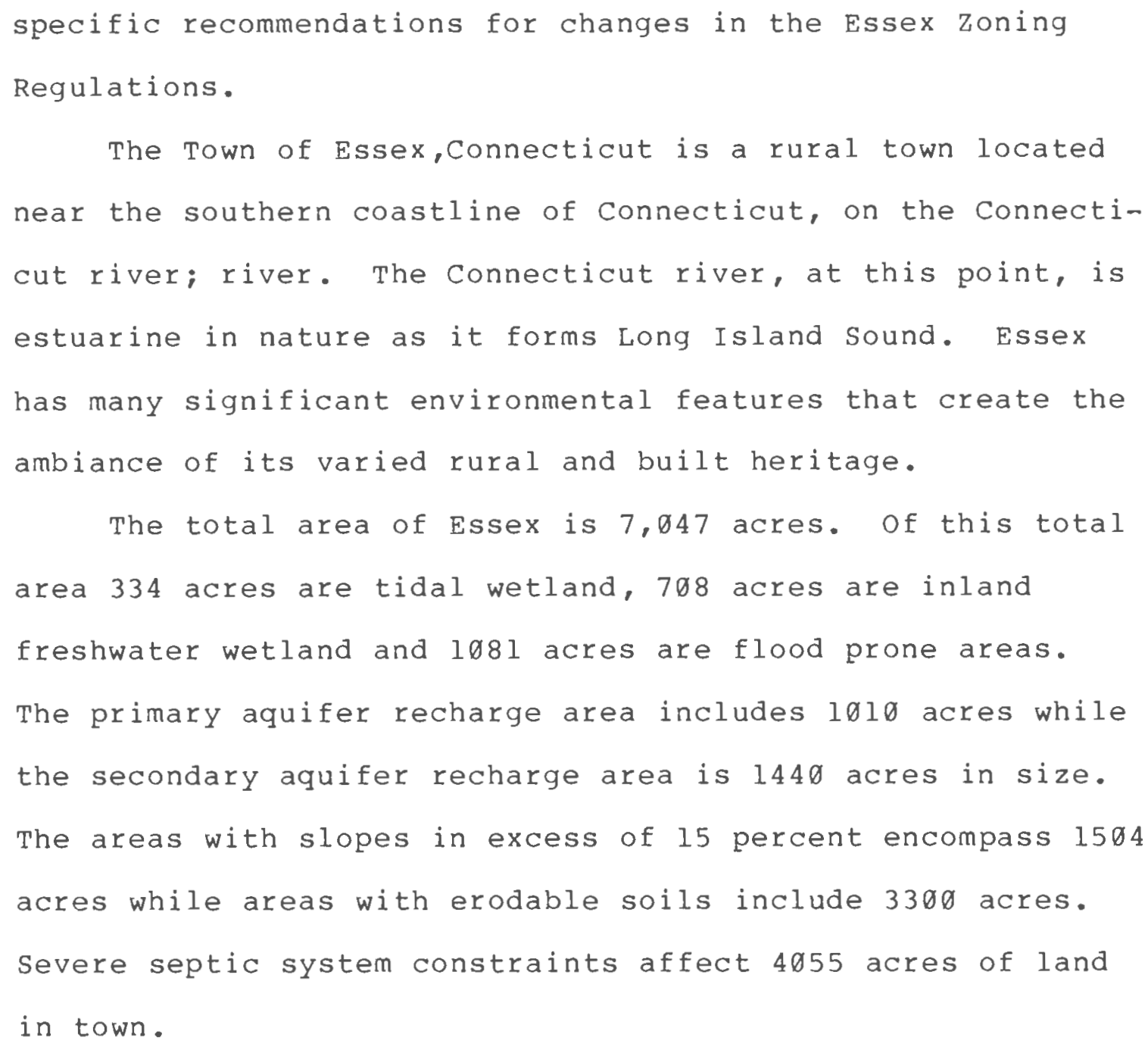




\section{Natural Features}

This chapter includes a description of several natural features of the town of Essex that are environmentally important to the town. These include streams, ponds, wetlands, flood prone areas, groundwater, steep slopes, erodable soils and septic system constraints. The values of each natural feature are described and a listing is provided of the kinds of impacts that development can cause to these natural features. Mapping of critical areas for each natural feature is provided.

\section{Streams and ponds}

\section{Value of streams and Ponds}

1. Public water supply

2. Groundwater recharge from streams and ponds especially during dry times of the year can help to keep groundwater levels up.

3. Flood prevention is helped by the water storage capacity of both streams and ponds.

4. Habitat for both aquatic and non-aquatic wildife.

5. Recreation. 
Impacts on Streams and Ponds

The negative impacts that the development of land cause for streams and ponds result to a great extend from stormwater runoff that is associated with development. Additional runoff is caused by the increase in impervious surfaces such as roofs, driveways and parking areas. This additional runoff frequently causes erosion and in turn the sedimentation problems that are described below. The second impact of development is that the runoff from development usually carries pollutants into nearby streams and ponds. Runoff from a city street during the first hour of a moderate to heavy storm contributes more pollutants to watercourses than would the untreated sewage from that same city for the same period of time (Tank 1976). Although Essex is not an urban area, it does have densely developed areas and should be aware of the potential impacts of non-point sources of water pollution. Sedimentation: The following are some of the potential impacts that sedimentation can have on streams and ponds.

1. Flooding potential can be increased when sedimentation raises the level of lakebeds and streambeds and thereby lowers their capacity to store flood waters.

2. Public water supplies can be reduced when sedimentation lowers the storage capacity of reservoirs.

3. Treatment costs of public water supplies can be increased because of the need to remove sediment from 
these water supplies.

4. Dredging of harbors and waterways can be made necessary because of sedimentation.

5. Sedimentation that destroys the food supply and spawning grounds of fish will reduce their populations.

6. Turbidity prevents light from reaching the bottom of streams and ponds thereby destroying the habitats that plant and fish 1 ife depend on.

7. Water pollution in addition to the sediment itself may be associated with sedimentation. Sediment may have adsorbed to it many different kinds of pollutants including insecticides, herbicides and plant nutrients such as nitrogen, phosphorous and potasium. When sediment enters a stream or pond it carries these pollutants with it and may later release them into a waterbody (Tank 1976).

Water Quality: Streams and ponds can be affected by both organic and inorganic pollutants as is described below.

1. organic pollutants can enter a waterbody from stormwater runoff. They can also occur when plants or aquatic wildlife die from the affects of chemical pollutants or sedimentation. These organic materials decompose using the available dissolved oxygen that is needed by fish. Most fish will die if the oxygen supply in water goes below four parts per million as is often the case in heavily polluted waters.

2. Chemical pollutants are found in the runoff from a 
developed area. Streets and parking areas can contribute road salts, petroleum products, traces of lead, asbestos fibers from brakes and polychlorinated byphenyls from deteriorated nylon tires. Pesticides and insecticides can enter runoff from lawns and gardens. On site sewage disposal systems can leech to the surface polluting runoff with nitrates, phosphates and bacteria. Landfills can add a broad range of pollutants.

3. Eutrophication can result in overproduction of aquatic plants because of phosphate pollution from developed areas. This causes fish kills, odors from rotting vegetation and degrades water quality for swimming. Thermal pollution: This form of pollution results because the runoff from the impervious surfaces of developed areas often has a higher temperature than the streams and ponds it enters. This causes the temperature of streams and ponds to increase and can result in harm to aquatic wildlife.

Mapping

Map 1 shows the location of streams and ponds in Essex. This map is based on the United States Geological Survey topographic quadrangles that cover the Essex area. These maps are the Deep River, Essex and old Lyme quadrangles. 


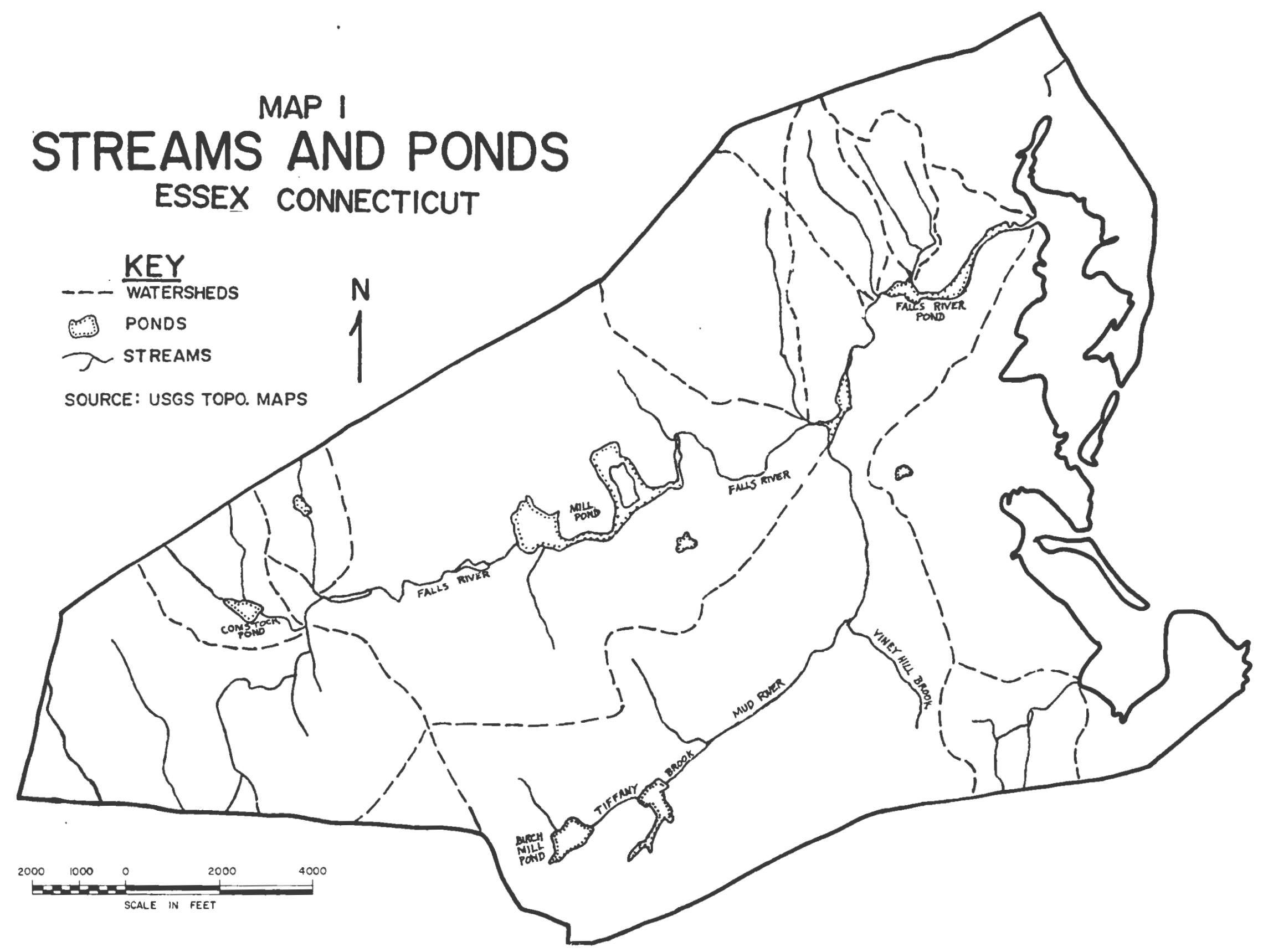




\section{WETLANDS}

Value of Wetlands

1. Purification of water takes place when wetland plants take up inorganic pollutants and use them as nutrients thereby changing them into an organic material that is not harmful to the environment.

2. Turbidity of water is lowered when it flows through a wetland because the wetland vegetation slows the rate of flow of the water allowing sediment to settle out.

3. Elood prevention is provided by wetlands when they act as stormwater retention areas.

4. Groundwater supplies are maintained when wetlands recharge aquifers.

5. Tidal wetlands moderate the impact of coastal storms.

6. High biological productivity is a characteristic of most wetlands. They provide breeding and feeding grounds for many kinds of wildlife. Tidal wetlands support the commercial fishing industry by providing a place for fish spawning.

7. Recreational, scientific and educational opportunities are also provided by a wetland setting.

Impacts on wetlands

As noted above, wetlands have a filtering capacity that allows them to withstand a certain amount of pollutants. If this level is exceeded however a wetland can be severely 
damaged or destroyed. Noted below are possible impacts that development can have on wetlands.

1. Eutrophication of a wetland can be increased dramatically when a wetland receives excessive loads of nutrients from a developed area. This can increase the rate of eutrophication to an extent that within a few years the wetland can be significantly altered.

2. Sedimentation of a wetland from high erosion rates can fill in and destroy the flood storage capacity of a wetland.

3. Turbidity in the water of a wetland can result from runoff with a high silt content. This can destroy plant life and aquatic wildlife in the same way as is described above in the section on streams and ponds.

4. The filling of wetlands with artificial fill in order to create buildable land has probably been the major activity responsible for destroying wetlands.

5. The pollution of wetlands with both organic and inorganic contaminants as described above in the section on streams and ponds can result from the developement of land.

Mapping

Map 2 shows the location of wetlands in Essex. This wetland mapping includes both inland and tidal wetlands and has been taken from mapping done by the connecticut 208 Program. Also shown on this map are flood prone areas, the discussion of which follows next in this study. 


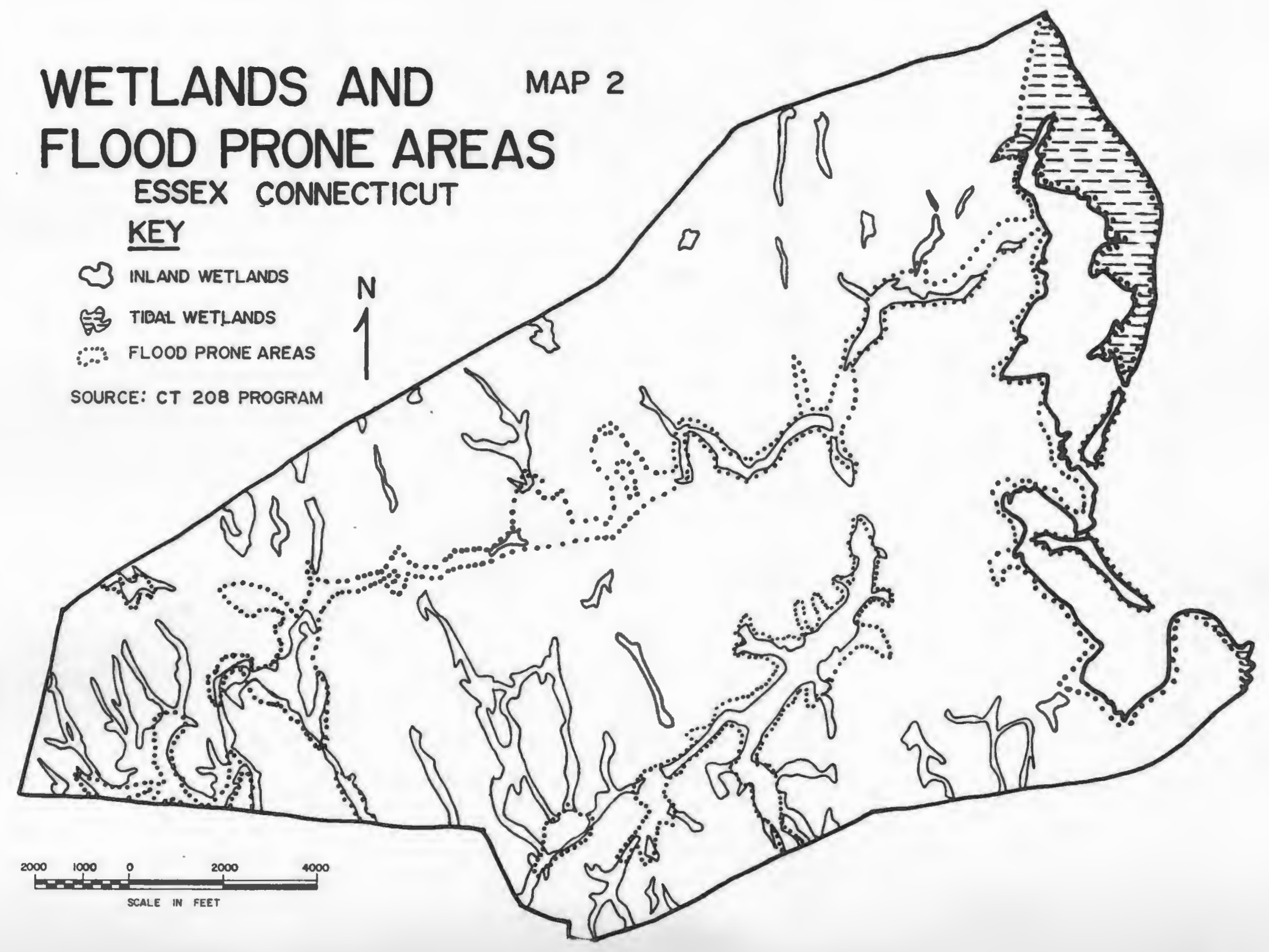




\section{FLOOD STORAGE AREAS}

Value of Flood Storage Areas

1. Flood prevention or reduction results when floodplains act as detention areas for flood waters.

2. Erosion from fast moving flood waters is reduced when the vegetation in floodplains slows the rate of flow of flood waters.

3. Aquifer recharge takes place during periods of time that flood areas are inundated.

4. Agricultural value results from flood waters depositing rich soils on floodplains.

5. Water quality is enhanced when floodplains filter out pollutants from flood waters.

6. Sedimentation of waterbodies and wetlands is reduced when the vegetation in floodplains slows down the flow rate of flood water and allows some of the silt to settle out.

Impacts on Flood Prone Areas

1. Filling of floodplains with artificial fill in order to create building sites increases flooding because the floodplain is no longer there to act as a detention area for flood waters.

a. Greater runoff because of increases in impervious surface and the loss of vegetation and organic litter that slow down runoff.

b. Loss of wetlands that act as flood detention areas. 
c. Sedimentation of streams and lakes causes a loss of storage capacity for flood waters.

2. Dams and dikes may be built in response to the threat of flood damage to buildings that have been located in the floodplain. The elimination of flooding because of dams also eliminates the benefits of flooding as outlined above including aquifer recharge, enrichment of farmland, water quality improvement and the reduction of floodwater turbidity. There are two additional benefits that may be lost from dam construction.

a. Pollution and sedimentation in streams and wetlands is cleared out by flood waters.

b. The lessening of stream flows that often follows from the construction of dams may lower groundwater levels and may cause wetlands to dry up.

Mapping

The mapping for flood prone areas is shown in Map 2. This mapping is based on the Flood Hazard Maps as prepared for the Federal Flood Insurance Program and indicates those areas that would be flooded on the average of once in 100 years. This means that in any given year that there is a $1 \%$ chance that flooding will occur. Areas that are larger than those mapped could be flooded less frequently than once in a hundred years and areas smaller than those mapped could be flooded more often. 


\section{GROUNDWATER}

Value of Groundwater

1. Drinking water is one of the main values of groundwater.

2. Irrigation of agricultural lands.

3. Water supply for businesses that require water for commercial and industrial processes.

4. Groundwater aquifers can help to purify water. As water travels through the aquifer the materials that make up the aquifer can filter out pollutants that are in the water as long as the rate of flow through the aquifer is not too fast. The percolation through the soil above the aquifer can also filter out impurities. A town has to be especially concerned about the quality of water entering an aquifer when there is little filtering because of shallow soil above the aquifer or because of a high permeability rate of the aquifer. This is especially important in Connecticut where shallow wells and sanitary septic systems are often located relatively close to each other in highly permeable stratified drift which lacks the ability to filter out many impurities (Davis and Dewiest 1966).

5. Flood prevention is enhanced by an aquifer when it takes up water when stream levels are high and then gradually releases it over a period of time.

6. Groundwater can help some streams and wetlands from going dry during dry periods by discharging into these streams or wetlands. 


\section{Impacts on Groundwater}

1. Pollution of an aquifier can result from polluted streams, ponds, wetlands or stormwater runoff that act as recharge sources for that aquifer. A description of the range of pollutants that can be introduced in this manner is described above in the section on streams and ponds .

2. Salt water intrusion can also cause the pollution of an aquifer. This is caused when an aquifer in a coastal area is depleted because of overpumping of wells or the loss of aquifer recharge areas because of development. Salt water then moves shoreward and displaces the fresh water that had been in the aquifer and may thereby contaminate wells in the area (Davis and Dewiest 1966).

3. Sedimentation of streams, ponds and wetlands can cut off the recharge of groundwater that might take place from these sources. This recharge of groundwater from surface water can be especially important in keeping wells usable during dry times of the year when stormwater runoff is not available to recharge groundwater.

4. Excavation of sands and gravels to obtain construction materials or create building sites can destroy an aquifer or open it up to pollution sources.

5. Over use of an aquifer by too much pumping can ary an aquifer out. When an aquifer has a reduction in artesian pressure, compaction of the aquifer can take place. This reduces and can almost eliminate the 
ability of that aquifer to supply water in the future (Davis and Dewiest 1966).

6. Loss of recharge areas can reduce groundwater levels when recharge areas are covered with impervious surfaces such as buildings and asphalt paving.

Mapping

Map 3 which follows shows the primary and secondary aquifer recharge areas as they have been mapped by the United States Geological Survey for the connecticut 208 program. The primary recharge areas are those areas with known and inferred coarse-grained and layered (coarse-over fine and fine over coarse) stratified drift with a water saturated thickness that is generally ten feet or greater. This primary recharge area would have the greatest value to the municipality as a water source.

The secondary recharge areas are adjacent till not drained by surface water and other adjacent areas of fine grained stratified drift. This secondary recharge area does not have as great a water producing potential for the town and therefore has a significantly lower municipal value than the primary recharge area described above.

\section{Steep Slopes and Erodable Soils}

These two factors are considered together because they are closely related. In fact, one of the criteria that is used by the soil Conservation service to classify erodable soils is the steepness of the slope on which that soil is 


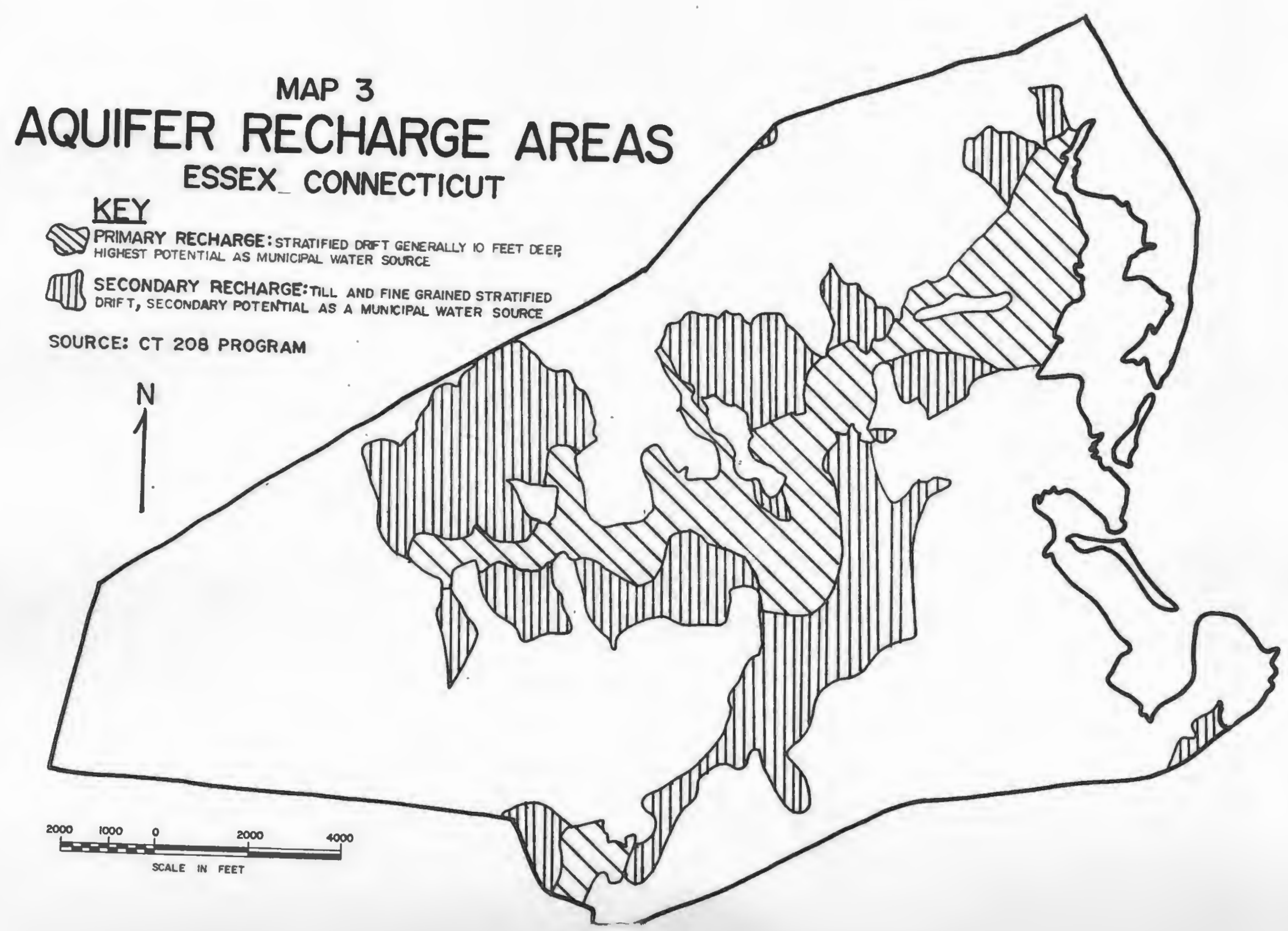


located. A soil, however, may be highly erodable even though it is not located on a steep slope, because of other characteristics of that soil. Eor this reason, the erodable characteristics of the soils in Essex have been mapped for this project in addition to the steep slopes in the town. steeply sloping areas and erodable soils do not have values to man that can be specifically listed as has been done for the other natural features considered in this study. The main value to be derived is the prevention of future environmental problems by developing these areas in such a way that environmental degradation does not take place.

Impacts of Development

1. Stormwater runoff can be increased because of development which increases the amount of impervious surface at a given site.

2. Erosion can be caused by development when this development causes increased runoff, removal of vegetation and organic litter and leaves large areas exposed to stormwater during construction. It should be noted here that soil which is fully protected by a covering of litter and humus contributes no sediment to stormwater runoff (Lull 1971). Development causes increases in both overland erosion and stream bank erosion. Stream bank erosion becomes greater because development causes an increase in the volume and flow 
rate of streams.

3. Sedimentation of streams lakes and wetlands results from the increased erosion that development can cause.

4. The aesthetic value of the landscape is often lost when steep slopes are improperly developed.

Mapping

Map 4, which follows, shows the areas in Essex that have slopes in excess of 15\%. Development in areas that have slopes that are this steep will frequently cause the problems that are described above. This mapping is based on mapping that was done for the Essex Plan of Development. Map 5 shows areas that have a high potential for erosion when disturbed for construction and community developments. Disturbed areas are defined as areas that have been excavated to a depth of about 18 inches or more. The soils having a high potential for erosion when disturbed were designated as such by the soil Conservation service based on the erodibility of the subsoil, permeability and steepness of slope. The mapping of these erosive soils is based on mapping done for the Connecticut 208 program.

\section{SEPTIC SYSTEM CONSTRAINTS}

This mapping of septic system constraints is especially important in Essex because of the lack of a public sewage disposal system. The entire town therefore utilizes on-site sewage disposal systems that are dependent for their proper functioning on the suitability of the soils for septic systems. There is no description of the public value or 
development impact provided in this section of the study because a constraint rather than a natural feature of the landscape is being mapped.

Map 6 which follows indicates the areas in Essex that have septic system constraints. This map has been developed from the soil survey for Middlesex county that has been done by the U.S. Soil Conservation Service. 


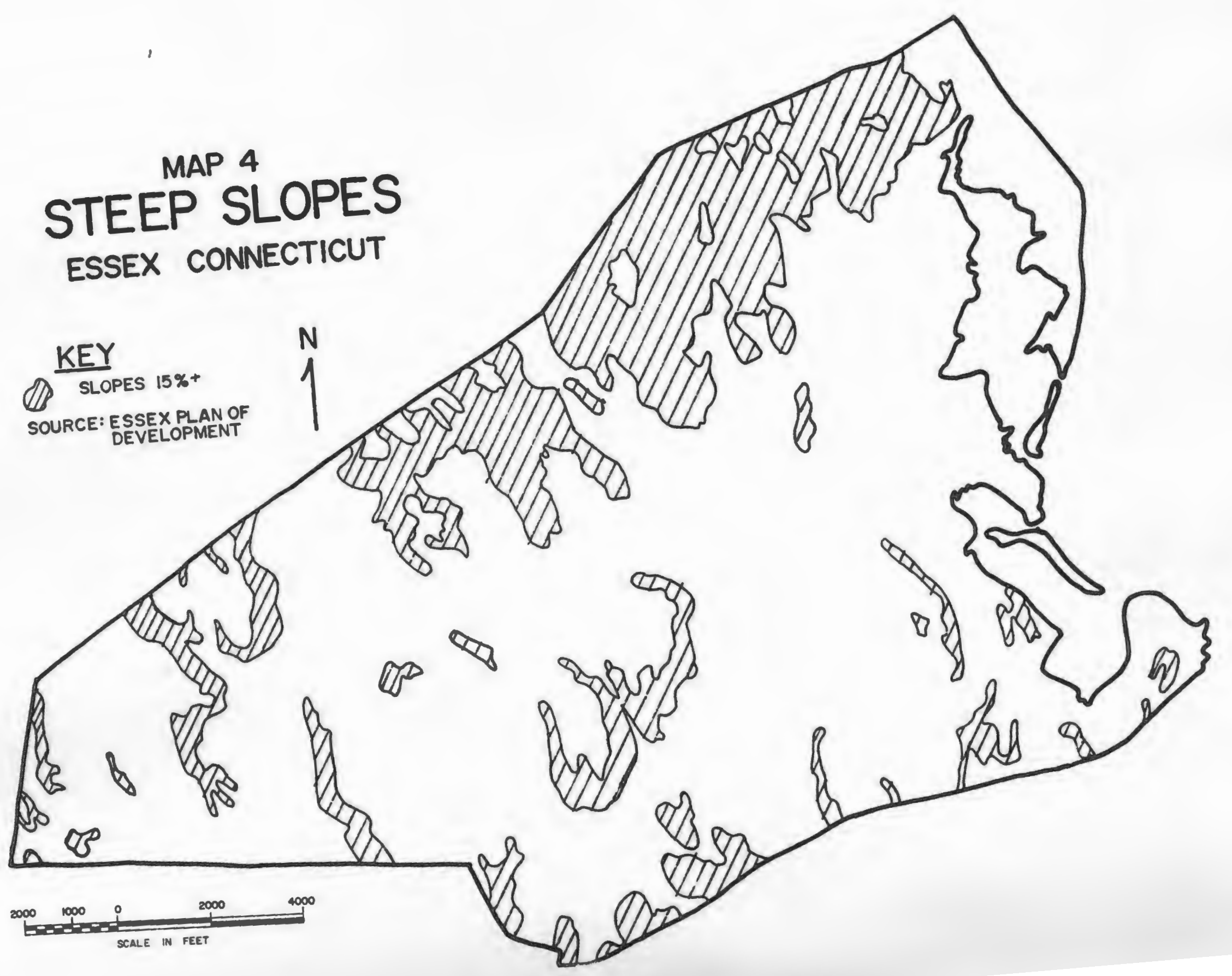




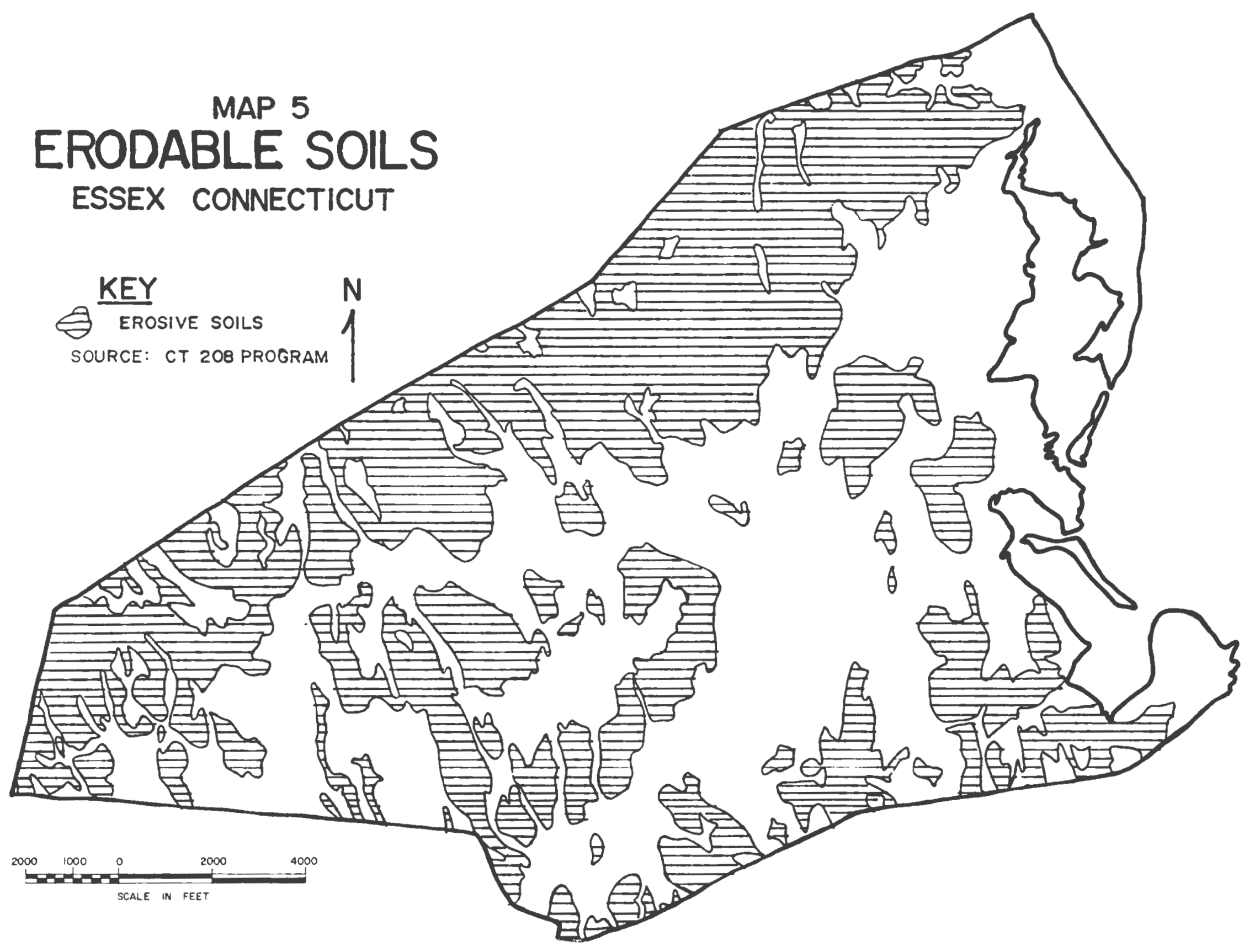




\section{SEPTIC MAP 6
SYSTEM CONSTRAINTS ESSEX CONNECTICUT}

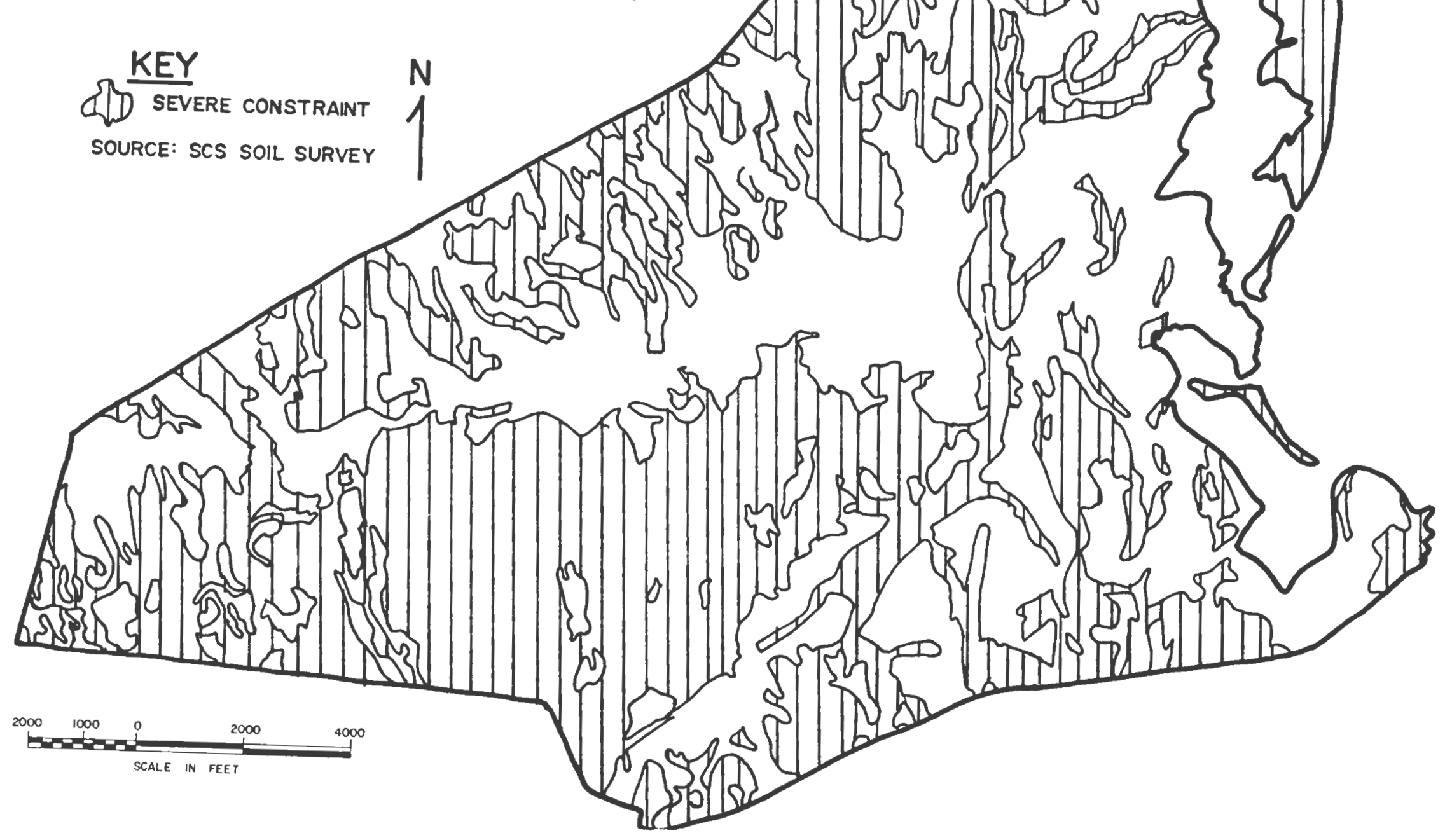


CHAPTER III

\section{Essex Zoning Regulations}

In this chapter the zoning districts designated by the Essex Zoning Regulations are reviewed in the light of the natural features of the town that were mapped in the previous chapter. The zoning regulations of Essex utilizes the following zoning districts:

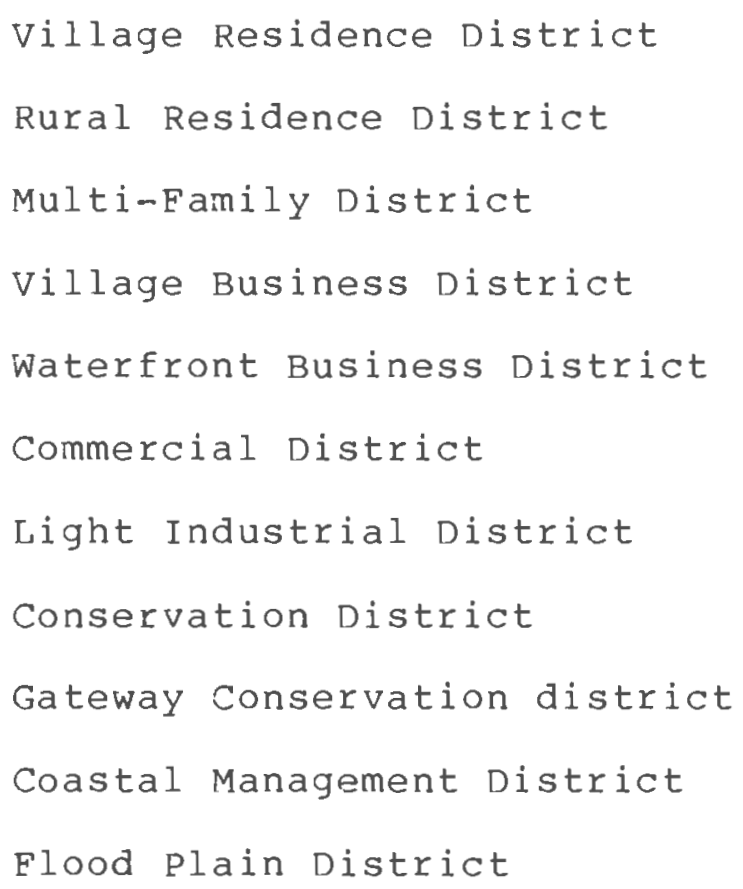




\section{MAP 7 ZONING ESSEX CONNECTICUT}

VR VILLAGE RESIDENCE

RU RURAL RESIDENCE

RU-M MULTI-FAMILY

VB VILLAGE BUSINESS

WF WATERFRONT BUSINESS

C COMMERCIAL

LI LIMITED INDUSTRIAL

CONS CONSERVATION

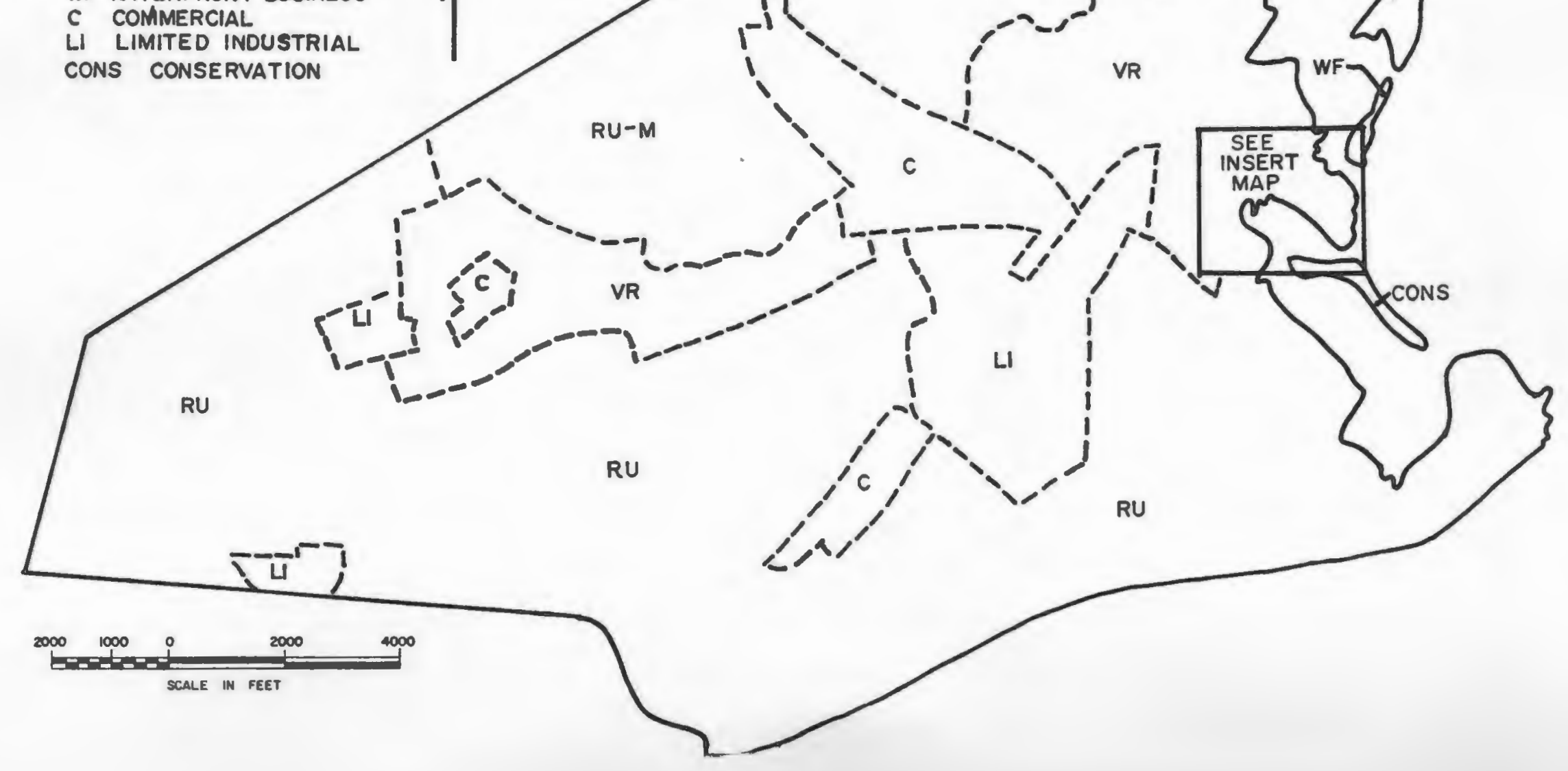




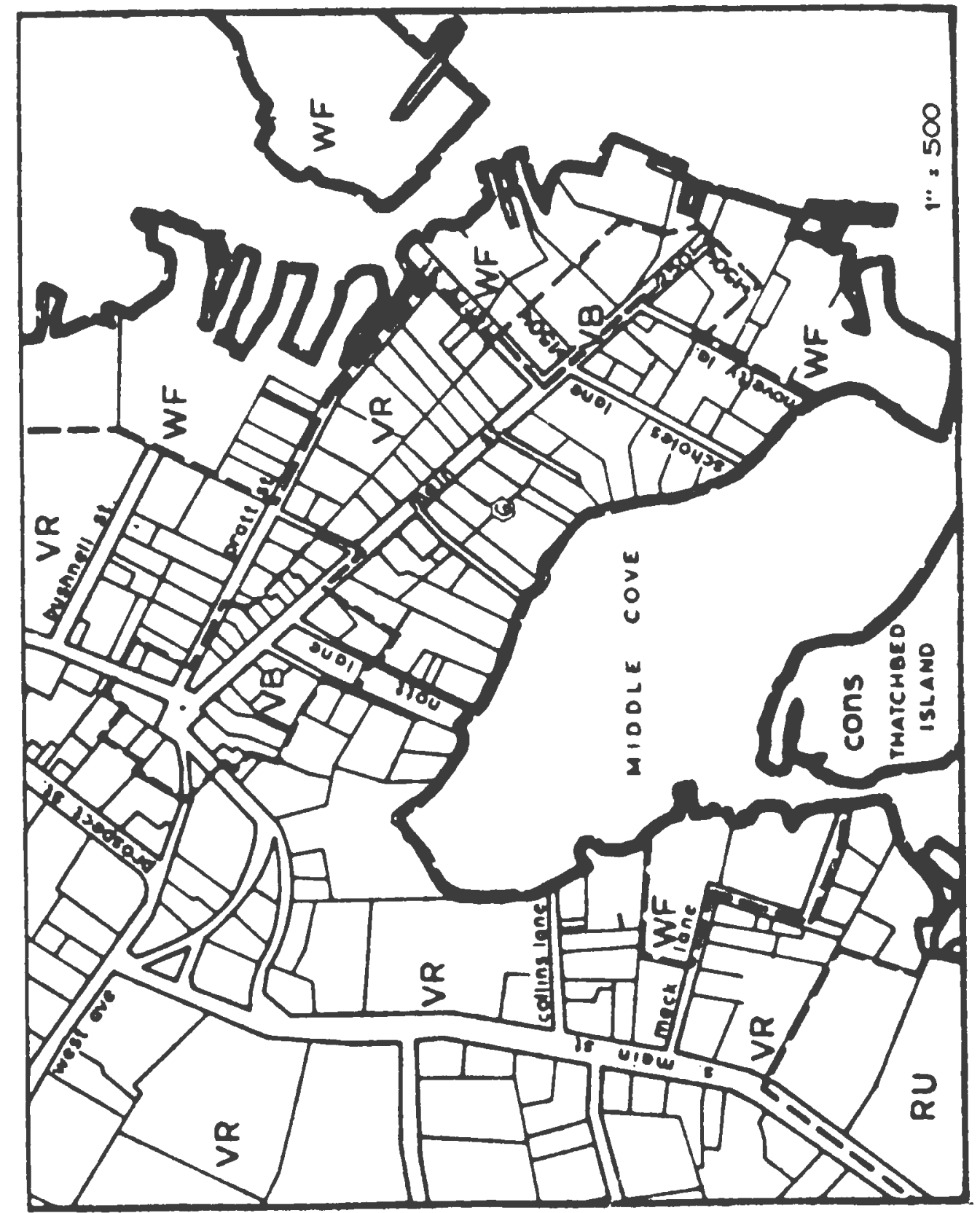


three zoning districts listed above are overlay districts which, are described in the text of the zoning regulations but not shown on the zoning map.

\section{Village Residence District}

The Village Residence District is essentially a zone allowing single family dwellings on sites with a minimum lot size of 30,000 square feet. Other permitted uses in this district are public schools and churches. special permit uses include private schools, clubs, libraries, museums, auditoriums and medical facilities.

The Village Residence Districts include those areas of town that have historically been a primary area of residential development. These districts include much of the more intense residential development that currently exists in town. There are two zones in town that are classified as Village Residence Districts. One district is located on the Falis River in the central part of the town. The Falls River is the major river in town and runs in an east-west direction through the center of town. A large pond associated with the Falls River is located along the northern edge of this first village residence district. The second village residence district is also located on the Falis River but in the eastern part of the town. Because these districts are located along a river, parts of them are made up of flood prone areas. There is 
very 1 ittle in the way of wetlands associated with these Village Residence Districts. The topography tends to be flat and these districts are for the most part in the areas of town with better potential for septic systems. Erodable soils make up a significant proportion of these districts. The main environmental constraint for the Village Residence District is the fact that they include a major part of the primary aquifer recharge area that exists in town.

Erosion and sedimentation controls are advisable in the Village Residence Districts because of the erodable soils and watercourses included in these districts. The Village Residence District located in the eastern part of town is covered by erosion and sedimentation controls because it is included in the Gateway Conservation District. The Gateway Conservation District is an overlay zone and is described later in this paper. These erosion and sedimentation controls should be extended to include the Village Residence District located in the central part of town in order to deal with the erosion potential in this district.

Because these districts contain about one half of the primary aquifer recharge area in town it is important that provision be made for the protection of these recharge areas. Added importance is given to the need for this protection by the high density of development located in these districts. Not all parts of the Village Residence District are over primary aquifer recharge areas and in addition there are primary aquifer recharge areas located 
outside of these districts. Because these recharge areas are not included in specific districts the best strategy is to use an overlay district that would provide protection to just those areas that function as aquifer recharge areas. A complete description of overlay districts is provided in the next chapter along with a general proposal for a groundwater protection overlay district for Essex.

A final recommendation for the Village Residence District would be the inclusion of a regulation limiting the increase in stormwater runoff that would be allowed from development in these districts. The best regulation in this respect would be the requirement that there be no increase in stormwater runoff allowed by new development.

\section{Rural Residence District}

The Rural Residence District covers over one half of the town and allows single family dwellings with a minimum lot size of 40,000 square feet. This district allows any use permitted in a village residence district and also allows agricultural uses, vegetable stands, parks and private boat landings. Any special exception use allowed in a Village Residence District is also allowed in a Rural Residence District by special exception. Other uses allowed by special exception are dog kennels, veterinary hospitals, horse stables, commercial greenhouses and cemetaries.

There are two Rural Residence Districts in town. One is located in the northeast corner of the town and the other is located along the southern and western borders of the 
town.

The Rural Residence Districts contain some of the more severe environmental constraints in the town. These districts include some wetland areas and flood prone areas. Extensive areas with erodable soils and soils with severe septic system constraints are associated with these districts. The Rural Residence District in the northeast corner of town has especially significant environmental problems. In addition to the constraints mentioned above, this specific district is covered for about three quarters of its area by slopes in excess of 15\%. The remaining one quarter of this district consists for the most part of primary recharge area.

Some of the recommendations for the Rural Residence District are similar to those that were made for the village Residence District in the previous section of this chapter. The use of erosion and sedimentation controls and the limitation of increases in stormwater runoff would help to minimize impacts related to wetlands, slopes and erodable soils. Groundwater impacts would be lessened by the use of a groundwater protection overlay zone. The next chapter discusses the use of cluster zoning which could be used to minimize development impacts in the Rural Residence District. One of the primary recommendations would be to modify the zoning of the Rural Residence District covering the northeast corner of the town. The minimum lot size for this district should be increased to two acres because of 
the severe environmental constraints in this area.

Multi-Family District

The Multi-Family District allows any of the permitted uses or special exception uses that are allowed in a Rural Residence District. In addition, multiple dwellings are allowed when a special exception is granted by the zoning Commission. The minimum lot area for this district is 40,000 square feet per family dwelling unit.

There is only one Multi-Family District in town and it is located in the north-central part of the town. This district is located next to the Rural Residence District in the northeast corner of town which was described in the previous section as having severe environmental problems for development. This Multi-Family District shares most of these same environmental problems.

This Multi-Family District has extensive areas with highly erodable soils, slopes in excess of $15 \%$ and severe septic system constraints. Only a small part of the district is a primary recharge area but a large part of it is a secondary recharge area. Only small parts of the district are in wetlands or flood prone land. The Falls River and a large pond associated with the Falls River are located in the southern part of this district.

The extensive environmental constraints of this MultiEamily District make it a poor site for the location of multiple family housing. It is recommended that the zoning for this district be changed to eliminate multiple family 
housing as a permitted use. It is suggested that the zoning be changed to only allow single family dwellings with a minimum lot size of two acres. This zoning district would be the same as that recommended in the previous section of this chapter for the Rural Residence District in the northeast corner of town. The other recommendations made in this previous section for a Rural Residence District would also apply here.

A problem with removing the multiple family use from this district is that there would not be any district in town that would allow the construction of multiple family housing. It is suggested that the Village Residence District be amended so that multiple family housing is allowed as a special exception use. The Village Residence District contains much of the land in town with the best environmental suitability for development. A large part of the land within the Village Residence District has been developed but there are still large parcels of undeveloped land remaining on which multiple family housing could be built.

\section{Business Districts}

This section will consider the two zoning district categories that are used for business areas in the central business district of Essex. The names of these two districts are the Village Business District and the Waterfront Business pistrict. The insert map that is included with the Essex Zoning Map shows the location of these 
districts.

The Village Business District allows single family dwellings and customary home occupations as permitted uses. special exception uses include retail stores, offices, restaurants and churces. The minimum lot area is 15,000 square feet.

The Waterfront Business District includes as permitted uses single family dwellings, marine related offices and marine related retail stores. Special exceptions are required for marinas, boat building or repairing facilities, wharves, slips, boat basins, commercial docks, yacht clubs and non-profit maritime museums. The minimum lot size is 30,000 squre feet.

The area that these districts cover, has historically been the primary area for commercial development in the town. Today virtually all of the land in these two districts has been developed. The only environmental constraint for these districts that is indicated by the environmental mapping included with this research project is a potential for flooding from the connecticut River. The Flood Plain District that is described later in this chapter provides adequate regulation of development in these flood prone areas. There is no recommendation made here for changes to these two zoning districts because the environmental mapping does not indicate any major environmental constraints that the zoning Regulations do not presently address. 
Commercial District

There are three commercial areas outside of the central business district which was just discussed. These three commercial areas are shown on the zoning map included with this chapter. Two of these commercial districts encompass village commercial districts in town that are of long historic standing. The Commercial District to the west end of town covers the business district for the village of Ivoryton. The business district for the village of Centerbrook is encompassed by the commercial District in the north-central area of town. A Commercial District created in recent times and known as Hitchcock corner is located in the south-central part of town.

The Commercial District allows a wide range of commercial uses including retail stores, offices, restaurants, hotels and service stations. Also any permitted or special exception use in a Village Residence District is allowed in a Commercial District. Theaters and other places of entertainment are allowed in a Commercial District by special exception. The minimum lot size requirement is 30,000 square feet.

These Commercial Districts include some of the better land in town for development from, an environmental perspective. The topography is flat and the septic system constraints are not severe in nature. The northern part of the Commercial District in Centerbrook is the only one with 
an indication of erodable soils. The Centerbrook and Ivoryton districts contain significant areas that are primary aquifer recharge areas. Centerbrook and Hitchcock Corner contain some wetland and flood prone areas. The Ivoryton district is located, to a large extent, in a flood prone area.

No recommendation is made here for specific changes to these Commercial Districts. It is felt that the changes already recommended for the zoning regulations will deal with the environmental constraints noted above or that the present provisions of the zoning regulations are adequate in this respect. The Flood Plain District already in the zoning regulations addresses the flood hazard problem. The use of erosion controls, runoff limitations and a groundwater protection district will help with the remaining environmental constraints.

Limited Industrial District

There are three Light Industrial Districts in Essex. These include two small districts at the west end of town and a large district in the center of town which includes most of the land zoned Limited Industrial.

This district permits a broad range of light industrial uses including wholesale, manufacturing and research. A special exception is needed for a use that involves refuse collection or processing. The minimum lot size is 80,000 square feet.

In addition to the regulation of use, the Light Indus- 
trial District utilizes a set of performance standards. Specific performance standards have been included for air quality and noise impacts. Particulates from smoke stacks are 1 imited to 30 grams per hour per acre of land included in the 1ot. Smoke is not allowed to exceed a density darker than Number 2 on the Ringleman Smoke Chart. It is required that the amount of dust produced not exceed 10 micrograms per cubic meter of air. Noise levels are not allowed to exceed 50 decibels. Another requirement is that heat, glare, vibration and radiation not be discernible from the outside of a structure. This combination of use controls and performance controls acts as a double check to insure that the impact of industrial development is minimized. The land area that these industrial districts include have severe environmental constraints. Especially considering the intense environmental pressure that some industrial uses can cause. All three Light Industrial Districts include extensive areas with severe constraints for septic systems, wetlands and flood prone areas. The large Light Industrial District in the center of town is almost completely covered by either primary or secondary aquifer recharge areas. In addition, all three districts have streams running through them.

Because of the environmental constraints found in these Light Industrial Districts it is recommended that the boundaries of these districts be adjusted so that they respond better to the environmental suitability of land. To 
make recommendaitons for the relocation of these boundaries could well involve a separate research project by itself. A broad range of factors should be considered, including such things as the adequacy of the circulation system, the impact on surrounding land uses, projected economic growth, and adequacy of existing public services. It is therefore recommended that a study be carried out to determine what changes should be made in the mapping designation of the Light Industrial District to make this district more compatible with the environmental constraints of the landscape in Essex.

Conservation District

The Conservation District puts a strict limit on the kinds of uses that can be developed in the district. The permittted uses in a Conservation District are limited to parks, playgrounds, forests, wildlife sanctuaries, boat landing areas, farming without tillage, grazing, reservations for game raising or hunting and other conservation activities carried on under private or public ownership.

There are two areas in the town that are classified as Conservation Districts. One district is a peninsula of land located along the eastern side of town extending into the Connecticut River. This peninsula is known as Great Meadow. The second area categorized as a Conservation District is Thatchbed Island which is located in the connecticut River to the east of the central business district. 
Great Meadow is a land area 200 acres in size on which sediment is deposited from the flooding of the connecticut River. The deposition of this sediment causes levees and creates a land form known as a pendant bar (Lord et al 1983). During extreme high tide part of the Great Meadow is submerged by the estuarine waters. The remaining part that is not submerged by these high tides is a flood prone area subject to flooding from the connecticut River. The soil type that is found on Great Meadow is Westbrook (WH) mucky peat which is a tidal wetland soil.

Thatchbed Island also has severe environmental constraints for development. The soil found on the island is Rumney (RU) fine sandy loam which is a tidal wetland soil. The island is also subject to flooding from the Connecticut River.

The strict limitation on permitted uses that are applied by the Conservation District are justified by the severe environmental constraints that are found in the areas to which this district is applied. Both Great Meadow and Thatchbed Island have severe limitations for development because of the wetlands and flood prone areas that encompass both of these areas completely. The provisions of the conservation District do a good job of protecting these environmentally sensitive areas and no recommendation is made here to change the regulation itself or the boundaries of the areas to which it applies. 
Gateway Conservation District:

The Gateway Conservation District was established by the state of connecticut to protect the environmental and scenic quality of the lower part of the connecticut River. This district extends inland for an average of about a mile along the Connecticut River in Essex. The Gateway Conservation District is an overlay zone so that its requirements are in addition to the requirements of the zoning district that is in place beneath the overlay district. The boundary of this zone was designated by state legislation that established the Gateway Conservation District. This legislation also required that the town incorporate into its zoning regulations provisions for the protection of the environmental features of the land within the Gateway District.

The Essex Zoning regulations include several requirements relating to the part of the Gateway District that is located in Essex. An erosion and sedimentaiton control plan is required. The commercial cutting of trees and the use of land for a dump are prohibited. The removal of earth products is prohibited except to the extent necessary for site improvements associated with the developement of a lot or an ajoining lot under the same ownership. In addition, no construction is allowed in a 50 foot buffer zone along the connecticut River or the lower end of the Falls River which is the main river draining 
through the center of Essex.

The Gateway Conservation District along with the Coastal Management District and Flood Plain District which follow, contain many of the most important provisions in the Essex zoning Regulations to protect the natural features of the town. The regulations pertaining to these districts are well written and no recommendations are made here to change them.

Coastal Management District

The Coastal Management District is an overlay zone that is required by state legislation. The section of the Connecticut River that Essex is bounded by is estuarine in nature and therefore comes under the provisions of the Connecticut's Coastal Management Act. The town is required by this act to carry out site plan review of significant land development activities that might take place in the Coastal Management District. The location of this district is delineated by the state legislation and includes an area that extends 1000 feet inland from the connecticut River. Most minor projects are exempt from this review. Single family dwellings are exempt if they are located at least 100 feet away from important coastal resources including tidal wetlands, coastal bluffs and escarpments, beaches and dunes. The town carries out site plan review under the zoning regulations to insure that proposed projects minimize their impact on the coastal resources mentioned above and on the environemntal quality of the area in general. 
Flood Plain District

The Flood Plain District is an overlay district that applies to all of the HUD flood hazard areas that are Classified as $A$ or $A I$ to $A-30$. These include all the areas that are in the 100 year flood plain. The inclusion of this overlay district in the Essex zoning Regulations is required by the federal government in order to qualify Essex for participation in the National Flood Insurance program. The purpose of most of the requirements in this district are to minimize the loss of life or property in case of a flood. The main environmental protection that is included is the stipulation that septic systems be designed to minimize or eliminate infiltration of flood waters into the system and the discharge from the system into flood waters. None of these overlay districts that are presently part of the Essex Zoning Regulations have been adopted independently by the town, they have all been required to some extent by the state or federal government. The next chapter of this research project outlines a recommendation for a new overlay district that would help protect the quantity and quality of the town's groundwater supplies. 
CHAPTER IV

Zoning Techniques

In this chapter, zoning techniques will be discussed that can be used to limit the environmental impact of land development in Essex. One of the primary characteristics of these techniques is that they provide greater flexibility to the zoning regulations of a community. The greater freedom that they provide can be used by the land developer to create a site design that will take into careful consideration the environmental sensitivity of the land. There is no guarantee however that this will happen; the community in its negotiations with the developer has to insure that the opportunities provided by these zoning techniques are taken advantage of. The zoning techniques that will be discussed in the following narrative include impact zoning, overlay zones, and cluster zoning.

\section{Impact zoning}

The technique of impact zoning involves the application of a performance standard that a development proposal must meet before it will be approved. Impact zoning can perhaps best be understood by comparison to the traditional 1 isting of permitted uses. This use specification standard often includes a listing of prohibited uses as well as permitted 
ones. Impact zoning on the other hand does not involve the listing of permitted and prohibited uses but rather involves the delineation of performance criteria that the development must meet.

Impact zoning includes a broad range of techniques from adoption of a standard that indicates $10 \%$ of the site must be in common open space to a more complex standard that might involve the use of a computer model to determine air quality impacts.

The use of a traditional listing of permitted uses could in theory be completely replaced by impact zoning. These traditional use specifications would be replaced by a comprehensive set of performance standards. If a proposal met the requirements it would be allowed on the site without consideration to the type of use. Under this situation any mix of residential, commercial or industrial uses would be allowed as long as they did not conflict with the performance standards that had been set. In practice however performance standards are usually combined with use specifications. One reason for the combination of these techniques is that our understanding of environmental impacts and other potential impacts is too limited to predict completely the potential impacts of a development proposal (Meshenburg 1976).

Performance standards have been used most extensively for industrial districts and are the most advanced in this area, especially for industrial emissions. Impact zoning 
involves the extension of performance standards to other areas of potential impact including environmental, fiscal and infrastructure (roads, schools, water supply etc.) impacts.

Environmental performance standards often utilize natural resource models. These models can help to predict environmental impacts such as air pollution increases in stormwater runoff and erosion potential. Sometimes a numerical limit can be set for the performance standard such as the requirement that there be a "zero" increase in runoff from a land development proposal. In other cases, a more general performance standard may be applied, such as the requirement that erosion and sedimentation be minimized to the fullest extent possible through the use of an erosion and sedimentation control plan. The extent of the erosion and sedimentation controls that are then utilized is determined by the specific sensitivity of the site to erosion.

One use of impact zoning in the Essex zoning Regulations in in the Gateway Conservation District. This is an overlay district that includes the area in Essex along the Connecticut River. A full description of the Gateway Conservation District was given in the previous chapter. A requirement in this district is that an erosion and sedimentation control plan be provided for any development that takes place in the district. This requires the least possible disturbance to vegetation and soil during 
development and the quick planting of disturbed areas after construction is complete. The use of sediment basins can be required by the zoning Commission. There is also a requirement in the Gateway Conservation District that satisfactory provision be made to accommodate effectively the increased runoff caused by changes in soil and surface conditions during and after development. This general standard for runoff does not provide as good protection for the town as the stipulation of a specific percent limitation on runoff. A broader use of runoff and erosion controls is advisable throughout the town.

An advantage of impact zoning is that it provides greater flexibility to the land developer that can lead to more innovative designs to reduce the impact on the natural features of a site. Impact zoning also reduces the need to predict the many impacts of a listing of permitted uses. The developers' engineer and other consultants must develop a plan that will meet the requirements of the performance standards. A better design for a site can result from impact zoning because it calls for the analysis of the unique natural features that exist on the site.

The use of impact zoning often requres a community to utilize more staff time and expertise than are requried in the administration of use specification standards. The negotiation process that impact zoning often results in can require not only the use of additional staff time but also the use of additional time on the part of elected officials. 
The town of Essex has limited time and expertise available to administer its zoning regulations, therefore it would be best not to utilize performance standards that are overly difficult to administer.

Based on the analysis of zoning districts that was carried out in the previous chapter it is recommended that impact zoning be used in the areas of runoff and erosion controls. Because the environmental constraints in Essex indicate potential impacts of this nature in all of the zoning districts described in the towns zoning Regulations it is recommended that these controls be made mandatory throughout the town.

It is suggested that the regulations for stormwater runoff require that there be no increase in stormwater runoff because of the development of a parcel of land. This will help to preserve the natural drainage system and prevent the stormwater runoff impacts that are outlined in Chapter I.

The section of the Essex zoning Regulations covering the Gateway Conservation District includes the requirement that erosion and sedimentation control measures be utilized in the development of land in that district. The required measures are as follows:

(1) The plan of development shall so integrate the improvements to be made with the topography and soils of the premises as to create the least erosion potential; 
(2) All natural vegetation shall be retained and protected except that which must necessarily be removed to carry out the plan of development;

(3) The area of land exposed by removal of natural vegetation at any one time during the course of development shall be kept to the minimum necessary to carry out the plan of development;

(4) When land is exposed during the course of development, such exposure shall be kept to the shortest possible duration;

(5) Whenever the Commission shall deem it necessary, temporary vegetation and/or mulching shall be used to protect areas exposed during development;

(6) Sediment basins (debris basins, desilting basins or silt traps) as required by the Commission shall be installed and maintained to remove sediment from run-off waters from land undergoing development;

(7) Provision satisfactory to the Commission shall be made to accommodate effectively the increased run-off caused by change in soil and surface conditions during and after development; and

(8) The permanent final vegetation and improvements shall be installed as soon as practical in the course of development. 
It is recommended that these erosion and sedimentation control measures be made mandatory throughout the entire town.

\section{Overlay Zones}

An overlay zone adds a number of requirements to the requirements of the zoning district that is presently in place. The requirements of both of these zones must be fulfilled when a project is built in the overlay zone. Overlay zones can be especially helpful in protecting environmentally sensitive areas such as a stream which may weave its way through several existing zoning districts. In this case, the overlay district can be mapped so that it coincides with a streambelt area along the stream. special requirements can then be set up for this streambelt which will help to protect the environmental quality of the stream.

One advantage of an overlay zone is that from a legal standpoint it is a well established zoning technique. An overlay zone gives clear public notice as to what areas will be affected by the regulation and as a zoning technique has not been seriously challenged in the courts (Meshenburg, 1976). From a legal standpoint overlay zones have a legal validity that is similar to that of traditional zoning districts. They are also developed and administered through the usual process. An overlay zone can be shown on the zoning map and a description of its provisions is provided in the text of the zoning regulation. 
The Essex zoning regulations presently utilize three overlay districts. These include the Gateway conservation District, Coastal Management District and Flood Plain District. The Gateway and Coastal Management districts provide special environmental protection to the area in Essex that is located along the connecticut River. The Flood Plain District applies to all areas in Essex that fall within the 100 year flood plain. These districts were described in detail in the previous chapter of this report. A problem which came up several times in the analysis of the zoning districts was the lack of protection for the primary aquifer recharge area. It is therefore recommended that an overlay district be created for the primary recharge area. The following is an outline of what should be included in this groundwater protection district.

One of the primary goals of this groundwater protection district is to insure that stormwater runoff remains on-site and is allowed to infiltrate into the soil and thereby recharge the groundwater reservoir. If the runoff controls previously recommended were instituted they could help to insure that this recharge takes place. If these runoff controls are not extended to cover the entire town then they should at least be required in the recharge area. The runoff controls in the groundwater protection distict should emphasize the need for retention rather than detention of runoff so that the stormwater is given adequate time to infiltrate into the soil. 
Another way to encourage groundwater recharge is to minimize the area of the lot that is covered by impervious surfaces. These impervious areas such as roofs and paved areas prevent the infiltration of runoff into the ground. The Essex zoning Regulations specify a maximum building coverage for each zoning area. The construction of improvements such as driveways and parking areas can however add substantially to the impervious area on a site. For the groundwater protection district it would be good to require a minimum lot coverage in order to make sure that an adequate part of the district has pervious coverage. Requiring that driveways and parking areas in the groundwater protection district use pervious materials is another way of maximizing groundwater recharge.

The removal of earth products should be prohibited in the groundwater protection district to prevent the loss of the materials that make up the aquifer or filter water before it reaches the aquifer. If a total prohibition of earth removal is not instituted then such removal should be limited to several feet above the spring high water table. This district should prohibit any uses that could potentially pollute the groundwater. This would include the prohibition of landfills and hazardous waste sites. The storage of road salts should not be allowed in this district. Restrictions should be placed on the commercial storage of gasoline or oil. If storage of these fuels is allowed in this district then fiberglass tanks should be required. 
Another provision that should be considered is the use of catch basins with oil traps. This would allow the oil to be removed from street and parking lot runoff before it has the opportunity to infiltrate down to the water table.

Cluster Zoning

Cluster zoning allows the reduction of individual lot size in housing developments and combines the unused land into common open space for environmental preservation and recreation.

The ownership of the common open space that results from cluster development can be handled in several different ways. A listing of ownership alternatives is provided below:

1) Private ownership with deed restricitons to insure that the land is kept in open space. This prevents tax loss to the community and provides for maintenance of the land by the owner.

2) Joint ownership by an organization such as a neighborhood group.

3) Deeding the land over to a group such as the town or a conservation organization. The town has to agree to ownership which it might do if the open space is important to the town as a whole i.e. aquifer recharge area.

4) Developer holds the land. 
Advantages

1) Preservation of environmentally sensitive areas is encouraged by cluster development. The developer can give increased attention to site planning that considers natural limitations. It can thus be used to preserve things such as wetlands, aquifer recharge areas and steep slopes.

2) Open space can be preserved for its recreation and aesthetic values. Recreational activities such as golf, swimming, hiking etc. can be provided for. Recreational activites may be more accessible than in conventional subdivisions.

3) Clustering can allow the linkage of open spaces creating a contiguous greenbelt.

4) Buffer areas can be created to separate incompatible land uses.

5) Clustering can bring about more creative site design which can allow for:

a) orienting houses for energy savings.

b) Separation of vehicular and pedestrian traffic.

c) Aesthetically interesting site design such as curvilinear streets, staggered setbacks and varied lot sizes. 
d) The preservation of environmentally sensitive areas.

6) Savings in development costs for the developer and later maintenance costs for the municipality can result. This is caused by such things as shorter street lengths and shorter utility lines.

As can be seen from this overview of Cluster zoning there are a wide range of benefits that can result from the use of this kind of development. One of these primary advantages is that land with poor environmental suitability for development can be used as common open space and kept out of development. The analysis in the earlier chapters of this report indicates that the land throughout Essex has many environmental constraints for development. As a way to help deal with these environmental constraints it is recommended that cluster zoning provisions be incorporated into the Essex Zoning Regulations. 


\section{CHAPTER V}

Conclusion

The land within the town of Essex has many significant environmental constraints for development. The zoning Regulations of the town respond well to some of these constraints. The location of zoning districts for commercial areas, conservation areas and many residential areas are well suited to the environmental features of the town. The location decisions for the industrial districts and for some of the residential districts however do not respond well to the environmental suitability of the land in Essex. The recommendations made in this research project are concerned not only with the location of zoning district boundaries but also deal with recommended changes that affect the overall provisions of the zoning regulations. The following is a specific listing of the changes that this research project recommends for the Essex Zoning Regulations.

1. The erosion and sedimentation controls that are required by the Gateway Conservation District should be extended so that they apply to all districts in the town.

2. The zoning regulations should include a requirement that there be no increase in stormwater runoff from a land development proposal.

3. A groundwater protection district should be 
developed that provides specific protection measures for the primary recharge area. The regulations for this district should be in accord with the provisions outlined in chapter IV of this research project.

4. The minimum lot size for the Rural Residence District located in the northeast corner of town should be changed from one acre to two acres.

5. The Multi-Family District should be changed to allow only single family dwellings on two acre lots.

6. Multiple family dwellings should be allowed in the Village Residence District.

7. Changes should be made in the locations of the Limited Industrial Districts so that these districts do not include land areas with a large number of environmental constraints. 8. Cluster zoning provisions should be incorporated into the Essex zonning Regulations. 


\section{BIBLIOGRAPHY}

Brooks, Richard oliver. Municipal Environmental ordinances. University of Rhode Isla $\overline{\text { d. }}$

Connecticut River Estuary Regional Planning Agency. Final Report Areawide Waste Treatment Management Planning. Old Saybrook Connecticut, 1979.

Cooperative Extension Service. Trees and Forests in an Urbanizing Environment. University of Massachusetts, 1971.

Davis, Stanley N.; Roger J.M. Dewiest. Hydrogeology. New York: John Wiley and Sons, 1966.

DiNovo, Frank. Planning Advisory Service Memo: Local Groundwater Protection Programs. Chicago: Planning Advisory Service, 1983.

Gilchrist, John A.; Gary B. Griggs. The Earth and Land Use Planning. North Scituate, Massachusetts: Duxbury Press, 1977 .

Hendler, Bruce. Caring for the Land. Chicago: The APA press, 1977.

Ladd, Elisabeth et al. Wetlands and the water Cycle. Lincoln, Massachusetts: Masachusetts Audubon Society, 1975.

Lord-Wood, Larson Associates. Essex Coastal Area Management Report. Essex Connecticut, $197 \overline{5}$.

Meshenburg, Michael J. The Administration of Flexible Zoning Techniques. Chicago: Planning Advisory Service, 1976.

Metropolitan Area Planning Council. Water Resources Protection Techniques. Boston, 1978.

McHarg, Ian L. Design With Nature. New York: Doubleday and Company, Inc., 1971.

Soil Conservation Service. Middlesex County Connecticut Soil Survey. 1976.

State of Connecticut Department of Environmental protection. Developers Handbook. Hartford.

Tank, Ronald W. Focus on Environmental Geology. New York: Oxford University Press, 1976.

Thurow, Charles et al. Performance Controls for Sensitive Lands. Chicago: Planning Advisory Service, 1975. 
Todd, Keith David. Ground Water Hydrology. New York: John wiley and Sons, 1959.

U.S. Department of Housing and Urban Development. Innovative Zoning: A Local official's Guidebook. 1977. 